TEME, г. XLIV, бр. 4, октобар - децембар 2020, стр. 1411-1428

\begin{tabular}{lr}
\hline \hline Оригинални научни рад & https://doi.org/10.22190/TEME190702083K \\
UDK 659.113.25:316.347
\end{tabular}

Одобрено за штампу: 1. 12. 2020.

\title{
DO SOCIO-CULTURAL FACTORS MATTER IN CREATING THE GENERAL LEVEL OF CONSUMER ETHNOCENTRISM?
}

\author{
Milan Kostić, Nenad Stanišić, Veljko Marinković* \\ University of Kragujevac, Faculty of Economics, Kragujevac, Serbia \\ *vmarinkovic@kg.ac.rs
}

\begin{abstract}
The aim of this study is to assess the impact of certain socio-cultural factors on consumer ethnocentrism, as well as to measure the impact of consumer ethnocentrism on the purchase of domestic products. In this context, the paper presents and tests a new model that contains five potential antecedents of consumer ethnocentrism (national identity, cultural openness, patriotism, religiosity, animosity towards the European Union). The results indicate that patriotism stands out as the strongest antecedent of consumer ethnocentrism. Interestingly, the study confirmed the statistically significant and relatively strong impact of animosity towards the European Union (EU) on the general level of consumer ethnocentrism. On the other hand, cultural openness does not belong to the group of statistically significant drivers of consumer ethnocentrism. The originality of the study lies in the specific construction of the research model, which is coloured with sociocultural variables - especially patriotism, religiosity and animosity towards the EU..
\end{abstract}

Key words: consumer ethnocentrism, national identity, cultural openness, patriotism, religiosity, animosity.

\section{ДА ЛИ СУ СОЦИО-КУЛТУРНИ ФАКТОРИ БИТНИ У КРЕИРАҢУ ОПШТЕГ НИВОА ПОТРОШАЧКОГ ЕТНОЦЕНТРИЗМА?}

\begin{abstract}
Апстракт
Циљ рада је процена утицаја одређених социо-културних фактора на потрошачки етноцентризам, као и мерење утицаја који потрошачки етноцентризам има на куповину домаћих производа. У том контексту, рад представља и тестира нови модел који садржи пет потенцијалних антецедената потрошачког етноцентризма (национални идентитет, културна отвореност, патриотизам, религиозност и анимозитет према Европској унији). Резултати показују да се патриотизам истиче као најјача антенцендента потрошачког етноцентризма. Занимљиво је да је студија потврдила статистички значајан и релативно снажан утицај анимозитета према Европској унији (EУ) на општи ниво потрошачког етноцентризма. C друге стране, културна отвореност не спада у групу статистички значајних покретача потрошачког етноцентризма.
\end{abstract}


Оригиналност студије лежи у специфичној конструкцији модела истраживања, који је обојен социо-културним варијаблама - нарочито патриотизмом, религиозношћу и анимозитетом према ЕУ.

Кључне речи: потрошачки етноцентризам, национални идентитет, културна отвореност, патриотизам, религиозност, анимозитет.

\section{INTRODUCTION}

The concept of ethnocentrism has attracted the attention of many researchers in the field of social sciences. The term was introduced into literature by Sumner in 1906, as a pure, individual psychological construction, in order to distinguish between individuals who belong and those who do not belong to a group (Shimp T. A., 1984; Pilar \& Belén, 2013). Ethnocentrism is the view to one's own interest group, where the group is the centre of everything and all other groups are scaled and rated with reference to it (Balabanis \& Diamantopoulos, 2004; Javalgi et al., 2005). Members of the group consider themselves superior, nurture their pride and vanity, and look at all other groups with contempt (Sharma et al., 1995). The term ethnocentrism was developed from two words: one is "ethnic", which means the group; and the other is "centrism" which means focus on the group (Jiménez-Guerrero et al., 2014).

Consumer ethnocentrism is derived from the concept of ethnocentrism and is associated with the patriotic feeling of an individual that it is advisable to buy domestic products. Consumer ethnocentrism is the term used to describe the necessity and morality to buy domestic products. Even if local product is of lower quality than a foreign product, the ethnocentric consumer will opt for it rather than for the foreign product (Cheng \& Zhen, 2004). Consumer ethnocentrism leads to the purchase of domestic products (Watchravesringkan, 2011) and at the same time it represents the degree of loyalty to domestic products (Wai et al., 2013). From the perspective of ethnocentric consumers, buying foreign products is immoral because it hurts the local economy and leads to job losses, thus provoking their contempt. The opposite of the ethnocentric consumer is the non-ethnocentric consumer. For this consumer, the origin of the product is not important because the product is evaluated on the basis of its own quality (Shimp \& Sharma, 1987). Also, consumer ethnocentrism could be a very important factor for investment in domestic economy. Alho (2015) underlines strong relations between consumption preferences for domestically produced food and supporting local community by investment capital in food industry.

Since the knowledge of consumer ethnocentrism is crucial for the formulation and implementation of companies' marketing strategies, the concept has been analysed by many authors (Chryssochoidis et al., 2007). Authors have considered the impact of various factors on consumer 
ethnocentrism, as well as the impact it has on customer preference to buy domestic products. The consumer behaviour itself, but also the one directed at the purchase of domestic products, is heavily influenced by the consumers' socio-cultural and ethnical background, demographic elements, etc. (NguyenHau et al., 2013; Šapić, et. al., 2018; Pentz, Terblanche, \& Boshoff, 2017; Correa \& Parente-Laverde, 2017). A number of factors stand out as drivers of consumer ethnocentrism, and the following factors, among others, are included in them: cultural openness (Shimp \& Sharma, 1987; Kottasz \& Bennett, 2006; Nijssen \& Douglas, 2004; Howard, 1990; Balabanis et al., 2001; Javalgi et al., 2005; Vida \& Reardon, 2008; Dmitrovic, et al., 2009); patriotism (Han, 1988; Shankarmahesh, 2006); national identity (Hong \& Wyer, 1990); religiosity (Sharma et al. 1995; Balabanis et al. 2002); animosity towards other nations and products produced by these nations (Swee et al., 2004). A review of the aforementioned literature was the basis for the design and testing of a new research model that contains five potential antecedents of consumer ethnocentrism (national identity, cultural openness, patriotism, religiosity, animosity towards the EU). Through the representation and the check of the validity of the proposed model's specific structure and testing of the impact of socio-cultural variables on consumer ethnocentrism, the paper has filled a gap in the existing literature.

\section{THEORETICAL BACKGROUND AND LITERATURE REVIEW}

\section{National Identity}

Studies testify that national identity stands out as an important driver of consumer ethnocentrism (Vida et al., 2008). National identity largely shapes the behaviour of an individual and solidarity of the individual with the group denotes how much the group affects his/her behaviour (Alden et al., 2010). It can be said that national identity is a subjective and multi-dimensional feeling that arises from a common socio-cultural experience, the experience of ancestors, as well as a sense of belonging and commitment to a national or ethnic group (Cleveland et al., 2013). National identity, in the narrowest sense, can be defined as the degree to which a given culture identifies with its own "cultural focus". "Cultural focus" is the ability of each group to observe significant deviations in the individual characteristics of its own culture from other groups' culture. It follows that national identity is a set of characteristics that belong to a culture and is thus distinguished from other cultures. As such, this concept allows marketing decision-makers to think globally and act locally, to realize where product standardisation is possible and where specialisation is necessary (Keillor et al., 1996). Consumers evaluate products, among other things, according to which nation produces them, or which nation is associated with the product (Hong \& Wyer, 1990). On this basis, an 
appropriate scientific hypothesis can be defined: H1 - National identity has a statistically significant effect on the level of consumer ethnocentrism.

\section{Cultural Openness}

Cultural openness can be defined as the "willingness to interact with people from other cultures and experience some of their artefacts or as awareness, understanding, and acceptance of other cultures" (Sharma et al., 1995). The assumption is that people who frequently interact with other cultures will be more open to accepting their values, habits and even products - they are more willing to buy imported products (Howard, 1990). Although some studies have concluded that cultural openness and ethnocentrism are negatively correlated (Shimp \& Sharma, 1987; Kottasz \& Bennett, 2006; Nijssen \& Douglas, 2004; Howard, 1990; Tantray, 2018), other studies have refuted this and conclude that it would be too simplified an approach to generalise that frequent cross-cultural interactions and understanding of other cultures reduce consumer ethnocentrism (Balabanis et al., 2001; Javalgi et al., 2005; Vida \& Reardon, 2008; Dmitrovic, et al., 2009). Even in the middle of the last century, Skinner (1959) concluded that members of certain groups, such as diplomats or frequent travellers, who have frequent contact with other cultures, could have considerably expressed consumer ethnocentrism (Rosenblatt, 1964). Based on the foregoing, the second research hypothesis has been defined: $\mathrm{H} 2$ - Cultural openness has a statistically significant effect on the level of consumer ethnocentrism.

\section{Patriotism}

Patriotism is the sense of pride of one's own country and desire to live in it and fight for it. It also implies respect and loyalty to the people who live in their own country (Granzin \& Olsen, 1998). This concept implies that in this love and support, there is no hatred and aggression towards other nations (Feshbach, 1987; Granzin \& Olsen, 1998). Kosterman and Feshbach (1989) and Druckman (1994) make a clear distinction between patriotism and nationalism with the basic conclusion that when it comes to patriotism, unlike nationalism, there is no negative attitude towards other nations. Regarding the concept of patriotism, some authors such as Adorno et al. (1950) distinguish between healthy patriotism and ethnocentric patriotism, where healthy patriotism is not associated with prejudices that one has towards other nations, while in ethnocentric patriotism, love for the nation and national state is associated with prejudices towards other nations (Akhter, 2007). Some studies have identified a statistically significant relationship between patriotism and consumer ethnocentrism (Han, 1988; Shankarmahesh, 2006). Based on this, the following research hypothesis 
can be proposed: H3 - Patriotism has a statistically significant effect on the level of consumer ethnocentrism.

\section{Religiosity}

Religiosity can be defined as "the degree to which beliefs in specific religious values and ideals are held and practiced by an individual" (Swinyard et al., 2001). That is, high belief in the existence of God perceived under historical and social trends in a society (Božović Parlić \& Božović, 2018). Until recently, religiosity has not been the subject of discussion in the research of consumer ethnocentrism. Its impact on consumer behaviour is partly covered through the variable of conservatism. Conservative people are those that "show a tendency to cherish traditions and social institutions that have survived the test of time" and "introduce changes only occasionally, reluctantly, and gradually" (Sharma et al., 1995, p. 28). In its extreme form, conservatism can manifest itself as religious intolerance (Wilson \& Patterson, 1968 in Sharma et al., 1995). Studies such as Sharma et al. (1995) and Balabanis et al. (2002) found a positive relationship between conservatism and consumer ethnocentrism.

Religiosity should be distinguished from belonging to a particular religion. The latter is synonymous with a particular faith or creed (such as Christianity or Islam), whereas the former portrays the focus of religion in directing a person's life in accordance with religious role expectations (Weaver \& Agle, 2002). The fourth research hypothesis is as follows: H4 Religiosity has a statistically significant effect on consumer ethnocentrism.

\section{Animosity Towards the EU}

Animosity in this context can be defined as "the remnants of antipathy related to previous or on-going military, political or economic events that will affect consumers' purchase behaviour in the international marketplace" (Klein et al., 1998). It develops as a result of past or current political, military, or economic events (Swee et al., 2004). Unlike consumer ethnocentrism, which refers to foreign products in general, animosity is directed towards a specific country or countries (Klein et al., 1998; Klein \& Ettenson, 1999; Al Ganideh, 2017). For example, a consumer can be non-ethnocentric to a very small extent and prone to evaluate a product solely on the basis of its value, yet still feel an aversion towards products from a certain country due to historical reasons, such as wars, economic sanctions and the like (Swee et al., 2004). Nisco et al. (2016) found that economic animosity directly influences consumer ethnocentrism. Based on this, authors included animosity towards the European Union (EU) in the model. Animosity towards EU was measured through consumers' attitudes towards companies which are based in the EU, since economically they are the best representatives of this group of countries. The following research 
hypothesis will be tested: H5 - Animosity towards the EU has a statistically significant effect on consumer ethnocentrism.

\section{Consumer Ethnocentrism vs. Intention to Purchase Domestic Products}

The last relationship to be tested in the research is the one between consumer ethnocentrism and the intention to buy domestic products. Studies that have dealt with this relationship suggest that consumer ethnocentrism leads to the purchase of domestic products (Watchravesringkan, 2011; Wai et al., 2013). Accordingly, the sixth research hypothesis is defined as: H6 Consumer ethnocentrism has a statistically significant effect on the intention to purchase domestic products.

Based on the hypothesis above, an appropriate research model, presented in Figure 1, was designed.

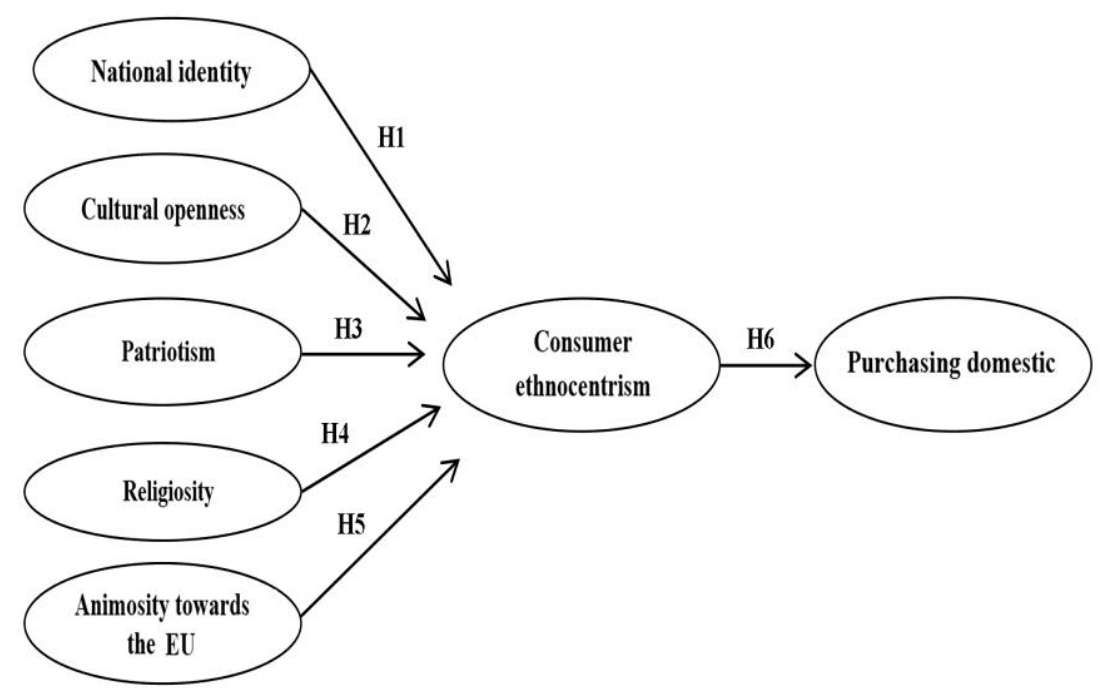

Figure 1. Research model Source: Authors

The impact of the five factors (national identity, cultural openness, patriotism, religiosity, and animosity toward the EU) on Serbian citizens' consumer ethnocentrism, as well as the impact of consumer ethnocentrism on the purchase of domestic products, will be analysed in the empirical part of the research (Figure 1). 


\section{METHODOLOGY}

\section{Sample and Procedure}

Data for the study was collected in six cities in Serbia. For primary data collection, the survey method was used. In the case of this research, the personal interview technique was applied and respondents were approached in city shopping malls, as they left after making a purchase. Thus, the convenience sample was used in the research. The use of this type of sample is common in marketing research (Widing, et al., 2003). Those respondents who accepted to participate in the research had the option to take the questionnaire home, in order to have enough time to consider and respond to the questions. At the same time, the respondents gave their phone numbers to the interviewers who contacted them, three days later to obtain the completed questionnaires. 221 correctly filled in questionnaires were collected. It is important to note that before the distribution of questionnaires, preliminary testing of questionnaire was conducted on a sample of 30 respondents.

As can be seen in the Table 1, there is a slightly higher percentage of women $(57 \%)$ in the sample compared to men $(43 \%)$. The most prolific age group in the sample is that of respondents aged 32-38 (24.4\%). The percentage of respondents who constitute other age groups ranged between $8.6 \%$ and $16.3 \%$. Regarding the level of education, most respondents in the sample have a university degree $(44.3 \%)$, followed by respondents with secondary education $(36.2 \%)$ and post-secondary education (19.5\%).

Table 1. Sample structure

\begin{tabular}{lrr}
\hline & Number of respondents & $\%$ \\
\hline Gender & & \\
$\quad$ Female & 126 & 57 \\
$\quad$ Male & 95 & 43 \\
Age & & \\
$18-24$ & 36 & 16.3 \\
$25-31$ & 29 & 13.1 \\
$32-38$ & 54 & 24.4 \\
$39-45$ & 35 & 15.8 \\
$46-52$ & 19 & 8.6 \\
$53-59$ & 29 & 13.1 \\
60 and over & 19 & 8.6 \\
Education level & & \\
Secondary school & 80 & 36.2 \\
Post-secondary & 43 & 19.5 \\
school & & \\
Faculty & 98 & 44.3 \\
\hline
\end{tabular}

Source: Author's calculations 


\section{Measures}

The research model that was designed included seven latent variables. Each variable was measured through at least three statements. Respondents expressed their degree of agreement with the statements on a seven-point Likert scale $(1-$ strongly disagree, 7 - strongly agree). The statements were selected based on a review of relevant literature. Consumer ethnocentrism was measured through four statements that were taken and adapted from Vida et al., (2008). The aforementioned study was the basis for the choice of three statements through which national identity was measured. The basis for the selection of statements through which cultural openness and the purchasing local products were measured was the study by Reardon and Vida, 2008. Both of the latent variables were measured with four statements. Patriotism was analysed on the basis of four statements taken from Kosterman and Feshbach, 1989. Religiosity was measured through four statements that were taken and adapted to the needs of the research from Ahmed et al., (2013). Finally, animosity was examined through three statements and the basis for their selection was from the studies conducted by Rose, et al. (2009) and Ahmed, et al., (2013).

\section{Statistical Analysis}

Statistical analysis was conducted in the Statistical Package for Social Sciences (SPSS, version 20.0) and AMOS (version 18.0). With regard to the statistical techniques utilised, reliability analysis, confirmatory factor analysis (CFA), and structural equation modelling (SEM) were applied.

Reliability analysis provided the opportunity, based on the value of Cronbach's alpha coefficient, to estimate the internal consistency of the statements used for measuring latent variable models. By calculating the value of the series of fit indices, the fit of the research model was tested within confirmatory factor analysis. Specifically, the values of the following fit indices were calculated: $\chi 2 / \mathrm{df}$; Comparative Fit Index - CFI; Incremental Fit Index - IFI; The Tucker-Lewis Index - TLI; The Root Mean Square Error of Approximation - RMSEA. In addition, the Average Variance Extracted (AVE) and Composite Reliability (CR) were calculated for each latent variable of the model. Finally, the testing of the hypotheses was conducted by using structural equation modelling. 


\title{
RESULTS OF RESEARCH AND DISCUSSION
}

\author{
Reliability and Confirmatory Factor Analysis
}

At the very beginning of the statistical analysis, the extent to which the statements are correlated with the variables for whose measurement they were used was evaluated by applying the item-to-total correlation approach. In order to obtain a more harmonious model, three statements (a statement for measuring cultural openness, a statement for measuring religiosity, and a statement for measuring local purchasing) were excluded from further analysis. Thereafter, for each variable of the model, the value of Cronbach's alpha coefficient was calculated. The findings showed an adequate level of internal consistency for the statements. For the national identity variable, Cronbach's alpha coefficient is 0.644 , which is higher than the minimum required threshold of reliability of 0.6 (Robinson, et al., 1991). In the case of the other variables, the value of Cronbach's alpha coefficient exceeds the value of 0.7 (Nunnally, 1978). In particular, the reliability of the other variables ranges from 0.805 (animosity) to 0.932 (consumer ethnocentrism). The findings of the reliability analysis are shown in Table 2.

Table 2. Reliability analysis

\begin{tabular}{lc}
\hline Variable & Cronbach's Alpha Coefficient \\
\hline National identity & 0.644 \\
Cultural openness & 0.878 \\
Patriotism & 0.892 \\
Religiosity & 0.883 \\
Animosity towards the EU companies & 0.805 \\
Consumer ethnocentrism & 0.932 \\
Purchasing domestic & 0.900 \\
\hline
\end{tabular}

Source: Author's calculations

In order to test the fit of the measurement model, confirmatory factor analysis was applied. The model exhibited an adequate fit which was evident from the values of the fit indices employed. The ratio of $\chi^{2} /$ df is 2.29 and this value is lower than the threshold of 3 (Carmines \& McIver, 1981). The values of the CFI, TLI, and IFI indices are higher than $0.9(\mathrm{CFI}=0.926$; $\mathrm{TLI}=0.910$; $\mathrm{IFI}=0.927)$, while the value of RMSEA is 0.077 and is located within the desired interval of $0.05-0.08$ (Hair et al, 2006). As for the RMSEA index, it can be concluded that values lower than 0.1 may be considered acceptable (Steiger, 1990). Also, all confirmatory factor loadings are higher than 0.5. Accordingly, the values are significant at the level of 0.05 . The average variance extracted for national identity is 0.41 . In the case of the other variables of the model, AVEs are higher than 0.5 and in the range of 0.59 and 0.78 . The composite reliabilities (CR) of all variables are higher than 0.6 (Bagozzi 
\& Yi, 1988). The results of the confirmatory factor analysis are presented in Table 3.

Table 3. Results of Confirmatory Factor Analysis

\begin{tabular}{|c|c|}
\hline Constructs and items (AVE and CR) & Loading \\
\hline \multicolumn{2}{|l|}{ National identity $(0.41 ; 0.67)$} \\
\hline $\begin{array}{l}\text { Serbian citizens possess certain cultural attributes that citizens } \\
\text { of other countries do not possess. }\end{array}$ & 0.513 \\
\hline Serbia has a strong historical legacy. & 0.629 \\
\hline Serbian citizens are proud of their national identity. & 0.745 \\
\hline \multicolumn{2}{|l|}{ Cultural openness $(0.73 ; 0.89)$} \\
\hline I like getting to know other cultural environments. & 0.971 \\
\hline I like being in touch with people who belong to other cultures. & 0.863 \\
\hline I like travelling to other countries. & 0.716 \\
\hline \multicolumn{2}{|l|}{ Patriotism $(0.67 ; 0.89)$} \\
\hline I am proud to be a citizen of Serbia & 0.844 \\
\hline I am emotionally attached to Serbia and everything that happens in it affects me & 0.765 \\
\hline I am proud to live in a country like Serbia & 0.882 \\
\hline I am proud when I see Serbian flag waving & 0.788 \\
\hline \multicolumn{2}{|l|}{ Religiosity $(0.72 ; 0.88)$} \\
\hline I regularly go to church & 0.827 \\
\hline Serbia would be a better country if we were more religious & 0.841 \\
\hline I consider myself a religious person & 0.874 \\
\hline \multicolumn{2}{|l|}{ Animosity towards the EU $(0.59 ; 0.81)$} \\
\hline If someone does business with companies from the EU, they should be careful & 0.773 \\
\hline EU companies are not reliable trading partners & 0.830 \\
\hline EU companies have unfair attitude towards Serbian companies & 0.694 \\
\hline \multicolumn{2}{|l|}{ Consumer ethnocentrism $(0.78 ; 0.93)$} \\
\hline Serbian products above all & 0.822 \\
\hline $\begin{array}{l}\text { We should buy products produced in Serbia } \\
\text { rather than allow other countries get rich at our expense }\end{array}$ & 0.845 \\
\hline It is always best to buy Serbian products & 0.931 \\
\hline $\begin{array}{l}\text { Although it may cost me more in the long run, however, } \\
\text { I prefer buying Serbian products }\end{array}$ & 0.927 \\
\hline \multicolumn{2}{|l|}{ Purchasing domestic $(0.75 ; 0.90)$} \\
\hline I mostly try to buy domestic products & 0.890 \\
\hline I first shop in stores that try to offer an abundance of domestic products & 0.871 \\
\hline
\end{tabular}

Structural equation modelling was implemented to test the hypotheses. The goodness-of-fit statistics of the proposed model showed that the model reasonably fits the data $\left(\chi^{2} / \mathrm{df}=2.31, \mathrm{CFI}=0.923, \mathrm{TLI}=0.909 ; \mathrm{IFI}=0.924\right.$, RMSEA $=0.077$ ). The SEM analysis results can be seen in Table 4 . As per Table 4, six effects were tested. The first five effects relate to the impact of national identity, cultural openness, patriotism, religiosity and animosity towards consumer ethnocentrism. Finally, the impact of consumer ethnocentrism on the purchase of domestic products was examined.

Of the five potential antecedents of consumer ethnocentrism, only the impact of cultural openness is not statistically significant (standardized estimate $=-0.063, \mathrm{p}>0.1$ ). The result testifies to the fact that openness to other cultures does not lead to weaker (or maybe increased) tendencies to 
purchase local products. Therefore, hypothesis $\mathrm{H} 2$ is not supported. The other four variables have a positive impact on consumer ethnocentrism, with patriotism having the strongest impact on consumer ethnocentrism (standardised estimate $=0.334, \mathrm{p}<0.01$ ). The findings of the research indicate that a 'love for country' also leads to increased tendency regarding intention to purchase local products. This confirmed hypothesis H3.

Table 4. Testing of hypothesised relationships

\begin{tabular}{lcc}
\hline Hypothesis & \multicolumn{2}{c}{$\begin{array}{c}\text { Standardized Conclusion } \\
\text { Estimate }\end{array}$} \\
\hline H1: National Identity $\rightarrow$ Consumer ethnocentrism & $0.200^{*}$ & Support \\
H2: Cultural openness $\rightarrow$ Consumer ethnocentrism & $-0.063^{\text {ns }}$ & Not support \\
H3: Patriotism $\rightarrow$ Consumer ethnocentrism & $0.334^{* *}$ & Support \\
H4: Religiosity $\rightarrow$ Consumer ethnocentrism & $0.124^{*}$ & Support \\
H5: Animosity towards the EU $\rightarrow$ Consumer ethnocentrism & $0.246^{* *}$ & Support \\
H6: Consumer ethnocentrism $\rightarrow$ Purchasing domestic products & $0.928^{* *}$ & Support \\
\hline
\end{tabular}

${ }^{* *}$ Significant at 0.01 level; ${ }^{*}$ Significant at 0.1 level; ${ }^{\text {ns }}$ Not significant

Source: Author's calculations

Hypothesis $\mathrm{H} 1$ predicted the relationship between national identity and consumer ethnocentrism. This hypothesis was supported by a standardised estimate of $0.200(\mathrm{p}<0.1)$. Animosity towards the EU has a somewhat stronger impact than national identity on consumer ethnocentrism ( standardized estimate $=0.246, \mathrm{p}<0.01$ ). This confirmed hypothesis H5 . Obviously, the sense of attachment of an individual to the nation to which they belong and their animosity towards EU companies, both have an impact on the increasing tendency towards the purchase of local products. Religiosity has the weakest impact on consumer ethnocentrism (standardised estimate $=0.124, \mathrm{p}<0.1$ ). However, this impact is statistically significant which confirms hypothesis H4. In the end, the results confirmed the very strong impact of consumer ethnocentrism on domestic purchasing (standardised estimate $=0.928, \mathrm{p}<0.01$ ). This confirmed hypothesis H6.

\section{CONCLUSIONS AND IMPLICATIONS}

\section{Summary of the Study}

The study had two main objectives. First, the study tested the fit of the new research model for measuring consumer ethnocentrism. Second, the statistical significance and strength of the impact of independent variables on consumer ethnocentrism were affirmed, as well as the impact of consumer ethnocentrism on domestic purchasing. The originality of the study lies in the specific construction of the model proposed. The model contains certain socio-cultural variables that have the role as potential drivers of consumer ethnocentrism, which provides the research with an innovative aspect. In the 
past, relatively few studies have tested the impact of religiosity, animosity towards the EU, cultural openness, national identity and patriotism on consumer ethnocentrism. In accordance with the results, the study has useful theoretical and managerial implications, but also implications related to approaching economic policy.

\section{Theoretical Implications}

General consumer ethnocentric tendencies were identified in the study as the study was not aimed at a particular group of products and services. Based on these findings, five of the hypotheses tested were confirmed. Only the impact of cultural openness on consumer ethnocentrism was not statistically significant. Obviously, the citizens' openness to other cultures is not associated with ethnocentric tendencies in the process of consumption. In relation to this, someone may be open to other cultures, be interested in exploring the customs of other nations and socialising with members of other cultures, but that does not mean that the person would be less directed towards the purchase of domestic products. The literature which has been published regarding the impact of cultural openness on consumer ethnocentrism is not clearly defined. Some studies suggest that cultural openness has a negative impact on consumer ethnocentrism (Vida \& Reardon, 2008; Dmitrovic, et al., 2009), while others deny this and conclude that it would be too simplistic to generalise that frequent cross-cultural interaction and knowledge of other cultures reduce consumer ethnocentrism (Balabanis et al., 2001; Javalgi et al., 2005; Vida \& Reardon, 2008; Dmitrovic, et al., 2009). It is necessary to note that the relationship between cultural openness and consumer ethnocentrism is a sensitive issue that has been the source of disagreement between researchers.

In contrast to cultural openness, the remaining four variables have a statistically significant positive impact on consumer ethnocentrism. Patriotism has the strongest impact, followed by animosity towards the EU, national identity and religiosity. The results are consistent with previous studies (Vida \& Reardon, 2008; Vida, et al., 2008; Ahmed, et al., 2013). The research findings clearly indicate that love for one's homeland, religious faith, and the sense of belonging to a certain national group, result in heightened and pronounced ethnocentric tendencies. Rose, et al. (2009) found that consumer ethnocentrism within Arab and Jewish markets, is positively associated with animosity towards the United Kingdom and Italy. Similarly, this study confirms that animosity towards the EU has a statistically significant impact on consumer ethnocentrism. Clearly, people who express doubts about the business and good intentions of EU companies in the Serbian market have a propensity to purchase local products. As a result, it was confirmed that consumer ethnocentrism has a very strong impact on domestic purchasing. The findings of the research are consistent with previous studies (Vida, et al., 2008; Vida \& Reardon, 2008). Moreover, 
Reardon et al. (2005) confirmed that in transitional economies, ethnocentric tendencies will transfer directly to negative views of foreign brand advertisements and thus indirectly develop attitudes towards these brands.

\section{Practical Implications}

Since the respondents expressed their attitudes on model variables on the seven-point Likert scale, they can be displayed in the form of ordinary arithmetic means (cultural openness $=6.11$; national identity $=$ 5.25; patriotism $=5.23$; religiosity $=4.59$; animosity $=4.33$; consumer ethnocentrism $=4.31$; domestic purchasing $=4.27$ ). The results indicate that there is a high degree of cultural openness, national identity, and patriotism in the observed sample. On the other hand, in the case of all other variables, respondent attitudes were moderate. These results and the results of the SEM analysis show that respondents prefer to travel and get to know other places, but they have an intrinsic sense of love for their own country and belonging to a national group, which leads them to purchase local products. Such a conclusion has certain managerial and macroeconomic implications. The managerial implications are concerned with multinational companies and the effort to reduce the impact of ethnocentrism. One way for multinational companies to reduce the impact of ethnocentrism is to invest more in countries where ethnocentrism is expressed, by establishing new or taking over existing companies. Local production uses local raw materials and could possibly develop local brands, thus giving the impression, in the eyes of consumers, that the product is local.

The macroeconomic implications of consumer ethnocentrism are varied. From the standpoint of the global economy, consumer ethnocentrism represents a latent threat to international trade, which is especially evident in times of economic crisis. Growing ethnocentrism is one of the explanations that accounts for the decrease in volume of international trade during a crisis is greater than the decrease in volume of a country's total trade. This discrepancy can be apportioned to increased feelings of patriotism in times of crisis. As previously mentioned, a method of overcoming this would be for multinational companies to invest in production in countries with strong consumer ethnocentrism, to create the impression that the product is, in fact, domestic.

From the standpoint of the national economy, consumer ethnocentrism is a positive phenomenon, which has been encouraged through "Buy Domestic" campaigns. As the research indicated, a high degree of cultural openness, a notable sense of national identity and patriotism in the respondents, any "Buy Domestic" campaign should contain elements that connect local products to national and state emblems of Serbia. In this manner, it would be advisable to ensure domestic products are coupled with the feeling of love for the country in the consumers' minds. In this context, 
promotional campaigns could contain messages in their slogans that point out that being a good citizen and a patriot means purchasing domestic products. Conversely, the high cultural openness of Serbian citizens should not be overlooked - any campaign should be clear that buying domestic products does not mean dismissing or rejecting other cultures.

\section{Limitations and Future Research}

The study has several limitations. Firstly, it was conducted only in one country, thus the results of consumer ethnocentrism determinants cannot be used to form a generalisation for the entire region of Southeast Europe. In this regard, it would be desirable to carry out a cross-cultural analysis of the citizens of several European countries in future research. Secondly, the paper identifies general ethnocentric tendencies, but the study was not directed at specific product categories. Thirdly, the results are presented at the level of the total sample; therefore, the study does not include a comparative analysis of the attitudes of the different demographic segments or areas of the respondents. Some studies show that the level of ethnocentrism may change from one location to another within one country (Karoui \& Khemakhem, 2019).

Additionally, although the model tested the impact of consumer ethnocentrism on local purchases, the research did not affirm the impact of consumer ethnocentrism on the unwillingness to buy foreign products. It would be useful if future research models contained some different variables, such as nationalism, or perceptions of trust in EU products.

\section{REFERENCES}

Adorno, T. W., Frankel-Brunswick, D. J., Levinson, N. R., Sanford, B. A., Levinson, M. H., \& Morrow, W. (1950). The Authoritarian Personality. New York: Harper Row.

Ahmed, Z., Anang, R., Othman, N., \& Sambasivan, M. (2013). To purchase or not to purchase US products: role of religiosity, animosity, and ethno-centrism among Malaysian consumers. Journal of Services Marketing, 27 (7), 551-563.

Akhter, S. H. (2007). Globalization, expectations model of economic nationalism, and consumer behavior. Journal of Consumer Marketing, 24 (3), 142-150.

Al Ganideh, S. F. (2017). Being Arab and American: Understanding Ethnocentric Tendencies for Arab American Consumers. Journal of Global Marketing, 30 (2), 72-86.

Alden, D. L., He, Y., \& Chen, Q. (2010). Service recommendations and customer evaluations in the international marketplace: Cultural and situational contingencies. Journal of Business Research, 63 (1), 38-44.

Alho, E. (2015). The effect of social bonding and identity on the decision to invest in food production. Journal of Behavioral and Experimental Economics, 59, 47-55.

Bagozzi, R. P., \& Yi, Y. (1988). On the evaluation of structural equation models. Journal of the Academy of Marketing Science, 16 (1), 74-94. 
Balabanis, G., \& Diamantopoulos, A. (2004). Domestic country bias, country-oforigin effects, and consumer ethnocentrism: a multidimensional unfolding approach. Journal of the Academy of Marketing Science, 32 (1), 80-95.

Balabanis, G., Diamantopoulos, A., \& Mueller, R. D. (2001). The impact of nationalism, patriotism and internationalism on consumer ethnocentric tendencies. Journal of International Business Studies, 32 (1), 23-38.

Balabanis, G., Mueller, R., \& Melewar, T. C. (2002). The relationship between consumer ethnocentrism and human values. Journal of Global Marketing, 15 (3/4), 7-37.

Božović Parlić, J., \& Božović, D. (2018). The Serbian Orthodox Church as an agent communication1 language. Teme, 42 (4), 1405-1418.

Carmines, E. G., \& McIver, J. (1981). Analysing models with unobserved variables: Analysis of covariance structures. In G. Bohmstedt, \& E. Borgatta, Social Measurement: Current Issues (pp. 65-115). Beverly Hills: SAGE.

Cheng, L. W., \& Zhen, X. C. (2004). Consumer ethnocentrism and willingness to buy domestic products in a developing country setting: testing moderating effects. Journal of Consumer Marketing, 21 (6), 391-400.

Chryssochoidis, G., Athanassios, K., \& Panagiotis, P. (2007). Ethnocentric beliefs and country-of-origin (COO) effect: Impact of country, product and product attributes on Greek consumers' evaluation of food products. European Journal of Marketing, 41 (11/12), 1518-1544.

Cleveland, M., Laroche, M., \& Hallab, R. (2013). Globalization, culture, religion, and values: Comparing consumption patterns of Lebanese Muslims and Christians. Journal of Business Research, 66 (11), 958-967.

Correa, S., \& Parente-Laverde, A.-M. (2017). Consumer Ethnocentrism, Country Image and Local Brand Preference: The Case of the Colombian Textile, Apparel and Leather Industry. Global Business Review, 18 (5), 1111-1123.

Dmitrovic, T., Vida, I., \& Reardon, J. (2009). Purchase behavior in favor of domestic products in the West Balkans. International Business Review, 18 (5), 523-535.

Druckman, D. (1994). Nationalism, Patriotism, and Group Loyalty: A Social Psychological Perspective. Mershon International Studies Review, 38 (1), 43-68.

Feshbach, S. (1987). Individual Aggression, National Attachment, and the Search for Peace: Psychological Perspectives. Aggressive Behavior, 13 (5), 315-325.

Granzin, K. L., \& Olsen, J. E. (1998). Americans' Choice of Domestic over Foreign Products: A Matter of Helping Behavior? Journal of Business Research, 43 (1), 39-54.

Hair, J. J., Black, W. C., Babin, B., Anderson, R., \& Tatham, R. (2006). Multivariate Data Analysis (6 ed.). Upper Saddle River, NJ: Prentice Hall.

Han, M. C. (1988). The role of consumer patriotism in the choice of domestic versus foreign products. Journal of Advertising Research, 28 (3), 25-32.

Hong, S., \& Wyer, R. S. (1990). Determinants of product evaluation: effects of the time interval between knowledge of a product's country of origin and information about its specific attributes. Journal Of Consumer Research, 17 (3), 277-288.

Howard, D. G. (1990). Understanding how American consumers formulate their attitudes about foreign products. Journal of International Consumer Marketing, 2 (2), 7-24.

Javalgi, R. G., Khare, V. P., Gross, A. C., \& Scherer, R. F. (2005). An application of the consumer ethnocentrism model to French consumers. International Business Review, 14 (3), 325-344.

Jiménez-Guerrero, J. F., Gázquez-Abad, J. C., \& Linares-Agüera, E. C. (2014). Using standard CETSCALE and other adapted versions of the scale for measuring consumers' ethnocentric tendencies: An analysis of dimensionality. Business Research Quarterly, 17 (3), 174-190. 
Karoui, S., \& Khemakhem, R. (2019). Consumer ethnocentrism in developing countries. European Research on Management and Business Economics, 25 (2), 63-71.

Keillor, B. D., Hult, G. M., Erffmeyer, R. C., \& Babakus, E. (1996). NATID: The development and application of a national identity measure for use in International Marketing. Journal of International Marketing, 4 (2), 57-73.

Klein, J. G., Ettenson, R., \& Morris, M. D. (1998). The Animosity Model of Foreign Product Purchase: An Empirical Test in the People's Republic of China. Journal of Marketing, 62 (1), 89-100.

Klein, J., \& Ettenson, R. (1999). Consumer animosity and consumer ethnocentrism: An analysis of unique antecedents. Journal of International Consumer Marketing, 11 (4), 5-24.

Kosterman, R., \& Feshbach, S. (1989). Toward a Measure of Patriotic and Nationalistic Attitudes. Political Psychology, 10 (2), 257-274.

Kottasz, R., \& Bennett, R. (2006). Ethnocentric tendencies amongst arts audiences. International Journal of Nonprofit and Voluntary Sector Marketing, 11 (4), 303-317.

Nguyen-Hau, L., Hai-Minh, T. N., \& Tuan, V. N. (2013). National identity and the perceived values of foreign products with local brands: The case of local wine in Vietnam. Asia Pacific Journal of Marketing and Logistics, 25 (5), 765-783.

Nijssen, E. J., \& Douglas, S. P. (2004). Examining the animosity model in a country with a high level of foreign trade. International Journal of Research in Marketing, 21 (1), 23-38.

Nisco, A. D., Mainolfi, G., Marino, V., \& Napolitano, M. R. (2016). Effect of economic animosity on consumer ethnocentrism and product-country images. A binational study on the perception of Germany during the Euro crisis. European Management Journal, 34 (1), 59-68.

Nunnally, J. C. (1978). Introduction to Psychological Measurement. New York: McGraw-Hill.

Pentz, C., Terblanche, N., \& Boshoff, C. (2017). Antecedents and consequences of consumer ethnocentrism: evidence from South Africa. International Journal of Emerging Markets, 12 (2), 199-218.

Pilar, F.-F., \& Belén, B.-V. (2013). Regional ethnocentrism: Antecedents, consequences, and moderating. Food Quality and Preference, 30 (2), 299-308.

Reardon, J., Mille, C., Vida, I., \& Kim, I. (2005). The effects of ethnocentrism and economic development on the formation of brand and ad attitudes in transitional economies. European Journal of Marketing, 39 (7/8), 737-754.

Robinson, J. P., Shaver, P. R., \& Wrightsman, L. S. (1991). Measures of Personality and Social Psychological Attitudes. San Diego: Academic Press.

Rose, M., Rose, G. M., \& Shoham, A. (2009). The impact of consumer animosity on attitudes towards foreign goods: a study of Jewish and Arab Israelis. Journal of Consumer Marketing, 26 (5), 330-339.

Rosenblatt, P. C. (1964). Origins and effects of group ethnocentrism and nationalism. Journal of Conflict Resolution, 8 (2), 131-146.

Šapić, S., Kocić, M., \& Radaković, K. (2018). The effect of a product's country of origin on the customer loyalty creation process. Teme, 42 (4), 1297-1317.

Shankarmahesh, M. (2006). Consumer ethnocentrism: an integrative review of its antecedents and consequences. International Marketing Review, 23 (2), 146-172.

Sharma, S., Shimp, T., \& Shin, J. (1997). Consumer Ethnocentrism: A Test of Antecedents and Moderators. Journal of the Academy of Marketing Science, 23 (1), 26-37. 
Shimp, A. T., \& Sharma, S. (1987). Consumer Ethnocentrism: Construction and Validation of the CETSCALE. Journal of Marketing Research, 24 (3), 280-289.

Shimp, T. A. (1984). Consumer ethnocentrism: The concept and preliminary test. Advances in Consumer Research, 11 (1), 285-290.

Skinner, G. W. (1959). The nature of loyalties in rural Indonesia. In G. W. Skinner (Ed.), Local, Ethnic, and National Loyalties in Village Indonesia (pp. 1-11). New Haven: Yale University.

Steiger, J. H. (1990). Structural model evaluation and modification: an interval estimation approach. Multivariate Behavioral Research, 25, 173-180.

Swee, H. A., Kwon, J., Ah, K. K., Siew, M. L., Chanthika, P., \& Soo, J. T. (2004). Animosity towards economic giants: what the little guys think. Journal of Consumer Marketing, 21 (3), 190-207.

Swinyard, W. R., Kau, A. K., \& Phua, H. Y. (2001). Happiness, materialism, and religious experience in the US and Singapore. Journal of Happiness Studies, 2 (1), 13-32.

Tantray, S. (2018). Consumer Ethnocentrism in 21st Century: A Review and Research Agenda. Business and Economics Journal, 9 (3), 1-12.

Vida, I., \& Reardon, J. (2008). Domestic consumption: rational, affective or normative choice. Journal of Consumer Marketing, 25 (1), 34-44.

Vida, I., Dimitrijevic, T., \& Obadia, C. (2008). The role of ethnic affiliation in consumer ethnocentrism. European Journal of Marketing, 42 (3/4), 327-343.

Wai, J. L., Ian, P., \& Rajat, R. (2013). "Bonds" or “Calvin Klein” Down-under: Consumer ethnocentric and brand country origin effects towards men's underwear. Journal of Fashion Marketing and Management: An International Journal, 17 (1), 65-84.

Watchravesringkan, K. (2011). Exploring antecedents and consequences of consumer ethnocentrism: evidence from Asian immigrants in the US. International Journal of Consumer Studies, 383-390.

Weaver, G. R., \& Agle, B. R. (2002). Religiosity and ethical behavior in organizations: a symbolic interactionist perspective. The Academy of Management Review, 27 (1), 77-98.

Widing, R., Sheth, J. N., Pulendran, S., Mittal, B., \& Newman, B. I. (2003). Customer Behaviour: Consumer Behaviour and Beyond. Melbourne: Thomson Learning.

Wilson, G. D., \& Patterson, J. R. (1968). A new measurement of conservatism. British Journal of Social and Clinical Psychology, 7 (4), 264-269.

\title{
ДА ЛИ СУ СОЦИО-КУЛТУРНИ ФАКТОРИ БИТНИ У КРЕИРАҢУ ОПШТЕГ НИВОА ПОТРОШАЧКОГ ЕТНОЦЕНТРИЗМА?
}

\author{
Милан Костић, Ненад Станишић, Вељко Маринковић \\ Универзитет у Крагујевцу, Економски факултет, Крагујевац, Република Србија
}

Резиме

Појам етноцентризам заокупља пажњу великог броја истраживача из сфере друштвених наука. Појам је уведен како би се направила разлика између појединаца који припадају одређеној групи и оних који не припадају одређеној групи. Из појма етноцентризам развијен је појам потрошачки етноцентризам, који је повезан са осе- 


\section{8}

ћањем појединца да је пожељно куповати домаће производе. Потрошачки етноцентризам се користи да се опише потреба и моралност куповине домаћих производа. За етноцентричног потрошача куповина иностраних производа је неморална (чак и када су у питању квалитетнији производи), јер штети домаћој привреди и доводи до губитка радних места. Спроведено истраживање је имало за циљ да испита утицај пет социо-културних фактора на потрошачки етноцентризам (национални идентитет, културна отвореност, патриотизам, религиозност и анимозитет према Европској унији; ЕУ). Такође, испитивана је и веза између потрошачког етноцентризма и куповине домаћих производа. Резултати показују да се патриотизам истиче као најјача антенцендента потрошачког етноцентризма. Студија је потврдила статистички значајан и релативно снажан утицај анимозитета према ЕУ на општи ниво потрошачког етноцентризма. С друге стране, културна отвореност не спада у групу статистички значајних покретача потрошачког етноцентризма. Добијени резултати упућује на корисне теоријске, менаџерске и макроекономске импликације истраживања. Што се тиче теоријских импликација, оне се огледају у оригиналности истраживања због конструисања иновативног модела истраживања. Менаџерске импликације односе се на стране компаније које већи нагласак треба да ставе на афирмацију домаћих брендове које имају у својим портфолијима. Што се тиче макроекономских импликација, неопходно је да доносиоци економских одлука, ако желе да повећају ниво куповине домаћих производа, повећају ниво потрошачког етноцентризма. То се може учинити путем кампање „Купујмо домаће”. Оно што у тој кампањи посебно треба подвући јесте да се куповином производа из Србије подстиче српска економија, али и да то не значи одрицање од путовања и упознања нових култура. 